\title{
Serum Levels Of Interleukin-12 And Tumour Necrosis Factor- $\alpha$ In Patients With Active And Inactive Rheumatoid Arthritis
}

\author{
Daad F.I. El Fouhil*, Amany M. Abdel Wahab*, \\ Nour H. Madbouli* and Sabila G. Mousa . \\ *Microbiology and Internal Medicine Departments, \\ Faculty of Medicine for Girls, Al-Azhar University
}

\begin{abstract}
:
Seventeen patients with active rheumatoid arthritis (RA) (group I) and fifteen patients with inactive RA (group II), in addition to ten healthy control subjects were included in the present study. All patients were evaluated clinically and biochemically according to the American College of Rheumatology (ACR) core set measures, and a comparison was set between both groups of patients. Serum levels of interleukin-12 (IL-12) and tumour necrosis factor- $\alpha$ (TNF$\alpha$ ) were measured using enzyme linked immunosorbent assay (ELISA) in all patients and control subjects. It was found that there was no significant difference in age, sex, disease duration, degree of disability or physician's and patient's global assessments between both groups of patients $(\mathrm{P}>0.05)$, but patients with active RA had significantly higher tender joint score, swollen joint score, visual analogue pain scale, erythrocyte sedimentation rate and $\mathrm{C}-$ reactive protein compared to patients with inactive RA $(\mathrm{P}<0.05)$. Detectable levels of IL-12 in serum were found in 13 out of 17 (76.5\%) active RA patients, 6 out of $15(40 \%)$ inactive RA patients and 1 out of $10(10 \%)$ healthy controls. TNF- $\alpha$ was also detected in the serum of 12 out of $17(70.6 \%)$ active RA patients, 7 out of $15(46.7 \%)$ inactive RA patients and 1 out of 10 (10\%) healthy controls, with significantly higher detectability and significantly higher mean serum levels of IL-12 and TNF- $\alpha$ in patients with active RA compared to patients with inactive RA and healthy controls $(\mathrm{P}<0.05)$. However, patients with inactive RA had significantly higher detectability and significantly higher serum levels of IL-12 and TNF- $\alpha$ compared to the healthy controls $(\mathrm{P}<0.05)$ which may reflect the role of IL-12 and TNF- $\alpha$ in the pathogenesis of RA. Serum levels of IL-12 correlated positively with TNF- $\alpha$ levels in serum in case of active RA patients $(\mathrm{r}=0.493)$ and inactive RA patients $(\mathrm{r}=0.474)$. It was concluded that significantly elevated serum levels of IL -12 and TNF- $\alpha$ may be associated with clinical and laboratory markers of activity of RA; and measurement of serum IL-12 and TNF- $\alpha$ levels could be used for assessment of RA activity. $\mathrm{IL}-12$ and $\mathrm{TNF}-\alpha$ may play an important role in the pathogenesis and inflammatory activity of RA.
\end{abstract}

\section{Introduction :}

Rheumatoid arthritis (RA) is an autoimmune disease characterized by the proliferation of synovium and the infiltration of chronic inflammatory cells. Cytokines and inflammatory cells are thought to be important in the initiation and perpetuation of RA (Kim et al., 2000).

Cytokines are small proteins produced by immune and non immune cells in response to foreign antigens (Peters, 1996).

Their central role include cell to cell communication, inflammatory response amplification and immune response regulation (Peters, 1999).

Interleukin-12 (IL-12) is recognized as a critical cytokine in terms of regulating the balance between $\mathrm{T}$ helper $1\left(\mathrm{Th}_{1}\right)$ and $\mathrm{T}$ helper $2\left(\mathrm{Th}_{2}\right)$ cells, as well as enhancing cytotoxic Tcell-mediated lysis and natural killer cell activity (Trinchieri, 1995). It has 
been shown to play a critical role in the regulation of immune responses in various autoimmune disease models, and it has been suggested to play a role in the pathogenesis of Tcell mediated autoimmune diseases (Ehrhardt et al., 1997).

Tumour necrosis factor- $\alpha(\mathrm{TNF}-\alpha)$ is another cytokine that has been shown to play a pivotal role in the pathogenesis of autoimmune diseases as RA. Apart from exerting direct pathogenic effects, it induces the production of other proinflammatory molecules that may amplify the inflammatory reaction (Brennan et al., 1992; Van den Berg and Van Lent, 1996).

The aim of the present study was to evaluate the serum levels of IL-12 and TNF- $\alpha$ in patients with active RA and patients with inactive RA compared to healthy control subjects. A correlation between the serum levels of these two cytokines in active and inactive RA patients was also investigated.

\section{Subjects and Methods :}

The present study was carried out on 32 RA patients who were attending the outpatient clinics of the Internal Medicine Department at Al-Zahraa University Hospital. They were diagnosed clinically and radiologically, and were subjected to laboratory investigations. Several clinical variables were evaluated in all patients according to the American College of Rheumatology (ACR) core set measures, including tender joint score, swollen joint score, visual analogue pain scale, physician's global assessment of disease activity, patient's global assessment of disease activity, degree of disability, erythrocyte sedimentation rate (ESR) and C-reactive protein (CRP). Rheumatoid factor (RF) was determined in all patients.

RA patients were divided according to rheumatoid activity into two groups : group I which included 17 patients (3 males and 14 females) with RA in the active stage (active RA) and with age range from 26 to 60 years (mean age $42.1 \pm 8.3$ years), and group II which included 15 patients (4 males and 11 females) with RA in the quiescent stage (inactive RA) and with age range from 25 to 62 years (mean age $40.4 \pm$ 7.4 years).

Ten apparently healthy subjects (group III) (2 males and 8 females) with no rheumatic or rheumatoid disease, and with age range from 20 to 57 years (mean age $39.8 \pm 5.1$ years) were also included in the present study as a control group.

Blood samples were taken from all patients and control subjects, centrifuged at 1500 r.p.m. for 10 minutes, and serum samples were collected and stored at $-20^{\circ} \mathrm{C}$ until use.

\section{Determination of serum IL-12 and TNF $-\alpha$ levels :}

Serum levels of IL -12 and TNF- $\alpha$ were determined by a solid phase sandwich enzyme linked-immunosorbent assay (ELISA) using commercial kits (Human IL-12 p70 ELISA Kit) and (TNF- $\alpha$ ELISA Kit) (Diaclone Research, France). According to the instructions of the manufacturer, standards of known IL-12 or TNF- $\alpha$ concentrations, control samples and tested serum samples were pipetted into the wells of the microtiter plates coated with a monoclonal antibody specific for IL-12 or $\mathrm{TNF}-\alpha$, then $50 \mu \mathrm{l}$ of a biotinylated monoclonal antibody specific for IL-12 or TNF- $\alpha$ were added to all wells and the plates were incubated for 3 hours at room temperature. After washing, $100 \mu l$ of the enzyme streptavidin peroxidase were added to the wells and a second incubation for 30 minutes at room temperature was performed. After washing to remove all the unbound enzyme, $100 \mu$ l of the substrate solution (Chromogen TMB substrate solution) were added to all wells and the plates were incubated in the dark for 12-15 minutes at room temperature. The enzymesubstrate reaction was stopped by adding $100 \mu$ l of the stop solution (1.8 N sulfuric acid solution). The absorbance of each well was read using a spectrophotometer at 450 $\mathrm{nm}$ as the primary wavelength and $620 \mathrm{~nm}$ as the reference wavelength. The concentration of IL-12 or TNF- $\alpha$ in each serum sample was determined from a corresponding standard curve obtained by 


\section{Daad F.I. El Fouhil et al}

assaying a dilution series of standard IL-12 or TNF- $\alpha$ in the same assays.

\section{Statistical analysis :}

Results were analyzed using standard statistical methods. Values were presented as mean \pm standard deviation. The chi square test was used to determine the significance difference among the studied groups. The correlation coefficient $r$ was also determined.

\section{Results :}

Comparison of personal, clinical and laboratory parameters between both groups of RA patients showed that there was no significant difference in age, sex, disease duration, degree of disability or physician's and patient's global assessments between the two groups of patients $(\mathrm{P}>0.05)$, but patients with active RA (group I) had significantly higher tender joint score, swollen joint score, visual analogue pain scale, ESR and CRP compared to patients with inactive RA (group II) $(\mathrm{P}<0.05)$. The rheumatoid factor was detected in all RA patients (Table 1).

Table (1) : Comparison of personal, clinical and laboratory parameters between patients with active $R A$ and those with inactive $R A$.

\begin{tabular}{|c|c|c|c|}
\hline Parameter & $\begin{array}{l}\text { Patients with active RA } \\
\text { (group I) } \\
\text { (n=17) }\end{array}$ & $\begin{array}{l}\text { Patients with inactive } \\
\text { RA } \\
\text { (group II) } \\
(\mathrm{n}=15)\end{array}$ & $P$ value \\
\hline $\begin{array}{l}\text { Age in years } \\
\text { mean } \pm \mathrm{SD}^{*} \text { (range) }\end{array}$ & $\begin{array}{l}42.1 \pm 8.3 \\
(26-60)\end{array}$ & $\begin{array}{l}40.4 \pm 7.4 \\
(25-62)\end{array}$ & $\begin{array}{l}\mathrm{P}>0.05 \\
\text { non significant }\end{array}$ \\
\hline Sex (male:female) & $3: 14$ & $4: 11$ & $\begin{array}{l}\mathrm{P}>0.05 \\
\text { non significan }\end{array}$ \\
\hline $\begin{array}{l}\text { Disease duration } \\
\text { in years } \\
\text { mean } \pm \mathrm{SD} \text { (range) }\end{array}$ & $\begin{array}{l}11.6 \pm 4.8 \\
(4-21)\end{array}$ & $\begin{array}{l}10.2 \pm 4.2 \\
(5-19)\end{array}$ & $\begin{array}{l}\mathrm{P}>0.05 \\
\text { non significant }\end{array}$ \\
\hline $\begin{array}{l}\text { Tender joint score } \\
\text { mean } \pm \text { SD (range) }\end{array}$ & $\begin{array}{l}31.1 \pm 6.9 \\
(12-64)\end{array}$ & $\begin{array}{l}12.7 \pm 3.8 \\
(0-20)\end{array}$ & $\begin{array}{l}\mathrm{P}<0.05 \\
\text { significant }\end{array}$ \\
\hline $\begin{array}{l}\text { Swollen joint score } \\
\text { mean } \pm \text { SD (range) }\end{array}$ & $\begin{array}{l}27.6 \pm 4.9 \\
(15-42)\end{array}$ & $\begin{array}{l}6.3 \pm 2.4 \\
(0-13)\end{array}$ & $\begin{array}{l}\mathrm{P}<0.05 \\
\text { significant }\end{array}$ \\
\hline $\begin{array}{l}\text { Visual analogue pain scale } \\
\text { in } \mathrm{mm} \\
\text { mean } \pm \mathrm{SD} \text { (range) }\end{array}$ & $\begin{array}{l}12.3 \pm 3.5 \\
(5-17)\end{array}$ & $\begin{array}{l}5.1 \pm 2.8 \\
(2-11)\end{array}$ & $\begin{array}{l}\mathrm{P}<0.05 \\
\text { significant }\end{array}$ \\
\hline $\begin{array}{l}\text { Physician's global } \\
\text { assessment } \\
\text { mean } \pm \text { SD (range) }\end{array}$ & $\begin{array}{l}3.1 \pm 1.4 \\
(1-5)\end{array}$ & $\begin{array}{l}1.9 \pm 0.3 \\
(1-3)\end{array}$ & $\begin{array}{l}\mathrm{P}>0.05 \\
\text { non significant }\end{array}$ \\
\hline $\begin{array}{l}\text { Patient's global assessment } \\
\text { mean } \pm \text { SD (range) }\end{array}$ & $\begin{array}{l}2.4 \pm 1.1 \\
(1-4)\end{array}$ & $\begin{array}{l}1.7 \pm 0.7 \\
(1-3)\end{array}$ & $\begin{array}{l}\mathrm{P}>0.05 \\
\text { non significan }\end{array}$ \\
\hline $\begin{array}{l}\text { Degree of disability } \\
\text { mean } \pm \text { SD (range) }\end{array}$ & $\begin{array}{l}2.6 \pm 1.2 \\
(1-4) \\
\end{array}$ & $\begin{array}{l}1.5 \pm 0.6 \\
(1-2)\end{array}$ & $\begin{array}{l}\mathrm{P}>0.05 \\
\text { non significant }\end{array}$ \\
\hline $\begin{array}{l}\text { Erythrocyte sedimentation } \\
\text { rate }(\mathrm{mm} / \mathrm{h}) \\
\text { mean } \pm \mathrm{SD} \text { (range) }\end{array}$ & $\begin{array}{l}59.2 \pm 26.9 \\
(16-130)\end{array}$ & $\begin{array}{l}15.5 \pm 6.7 \\
(3-61)\end{array}$ & $\begin{array}{l}\mathrm{P}<0.05 \\
\text { significant }\end{array}$ \\
\hline $\begin{array}{l}\text { C-reactive protein }(\mathrm{mg} / \mathrm{l}) \\
\text { mean } \pm \mathrm{SD} \text { (range) }\end{array}$ & $\begin{array}{l}30.8 \pm 8.7 \\
(14.4-83.7)\end{array}$ & $\begin{array}{l}13.1 \pm 4.9 \\
(6.2-44.8)\end{array}$ & $\begin{array}{l}\mathrm{P}<0.05 \\
\text { significant }\end{array}$ \\
\hline $\begin{array}{l}\text { Rheumatoid factor } \\
\text { Number of positive } \\
\text { (percentage) }\end{array}$ & $17(100 \%)$ & $15(100 \%)$ & \\
\hline
\end{tabular}

* $\mathrm{SD}=$ standard deviation.

Determination of serum levels of IL-12 in the RA patients and the healthy control subjects showed that 13 out of $17(76.5 \%)$ patients with active RA (group I), 6 out of 


\section{Serum Levels Of Interleukin-12..........}

15 (40\%) patients with inactive RA (group II) and 1 out of $10(10 \%)$ healthy control subjects (group III) had detectable levels of IL-12 in serum $(>5 \mathrm{pg} / \mathrm{ml})$, with significantly higher detectability (positivity) of $\mathrm{IL}-12$ in active RA patients compared to inactive RA patients and healthy controls $(\mathrm{P}<0.05)$. The mean level of serum IL-12 was significantly higher in patients with active RA than in patients with inactive RA and the healthy control $(\mathrm{P}<0.05)$. However, patients with inactive RA had significantly higher detectability of IL-12 in serum, and significantly higher serum IL-12 levels compared to the healthy controls $(\mathrm{P}<0.05)$ (Table 2).

Table (2) :Serum IL-12 in active RA patients, inactive RA patients and healthy controls.

\begin{tabular}{|c|c|c|c|c|}
\hline IL-12 & $\begin{array}{l}\text { Active RA patients } \\
\text { (group I) } \\
(\mathrm{n}=17)\end{array}$ & $\begin{array}{c}\text { Inactive RA } \\
\text { patients (group II) } \\
(\mathrm{n}=15)\end{array}$ & $\begin{array}{l}\text { Healthy controls } \\
\text { (group III) } \\
(\mathrm{n}=10)\end{array}$ & $P$ value \\
\hline $\begin{array}{l}\begin{array}{l}\text { Number of } \\
\text { (percentage) }\end{array} \\
\end{array}$ & $13(76.5 \%)$ & $6(40 \%)$ & $1(10 \%)$ & $\begin{array}{l}* \mathrm{P}<0.05 \\
\text { significant }\end{array}$ \\
\hline $\begin{array}{l}\text { Levels of IL-12 } \\
(\mathrm{pg} / \mathrm{ml}) \\
{[\text { for patients : }} \\
\text { mean } \pm \text { SD (range) }] \\
\end{array}$ & $\begin{array}{l}57.9 \pm 11.8 \\
(16.6-98.3)\end{array}$ & $\begin{array}{l}28.6 \pm 8.5 \\
(10.7-70.4)\end{array}$ & 7.5 & $\begin{array}{l}* \mathrm{P}<0.05 \\
\text { significant }\end{array}$ \\
\hline $\begin{array}{l}\text { Group I versus } \\
\text { Group II versus }\end{array}$ & $\begin{array}{l}\text { group II } \\
\text { group III } \\
\text { group III }\end{array}$ & $\begin{array}{l}\mathrm{P}<0.05 \\
\mathrm{P}<0.05 \\
\mathrm{P}<0.05\end{array}$ & & \\
\hline
\end{tabular}

Tumour necrosis factor- $\alpha$ was found in detectable levels $(>10 \mathrm{pg} / \mathrm{ml})$ in the sera of 12 out of $17(70.6 \%)$ patients with active RA (group I), 7 out of $15(46.7 \%)$ patients with inactive RA (group II) and 1 out of 10 (10\%) healthy control subjects (group III), with significantly higher detectability (positivity) of TNF- $\alpha$ in active RA patients compared to inactive RA patients and healthy controls $(\mathrm{P}<0.05)$. The mean level of serum TNF- $\alpha$ was significantly higher in patients with active RA than in patients with inactive RA and the healthy control $(\mathrm{P}<0.05)$. However, patients with inactive RA had significantly higher detectability of $\mathrm{TNF}-\alpha$ in serum, and significantly higher serum $\mathrm{TNF}-\alpha$ levels compared to the healthy controls $(\mathrm{P}<0.05)$ (Table 3$)$.

Table (3) :Serum TNF- $\alpha$ in active RA patients, inactive RA patients and healthy controls.

\begin{tabular}{|c|c|c|c|c|}
\hline $\mathrm{TNF}-\alpha$ & $\begin{array}{l}\text { Active RA patients } \\
\quad \text { (group I) } \\
(\mathrm{n}=17)\end{array}$ & $\begin{array}{c}\text { Inactive RA patients } \\
\text { (group II) } \\
(\mathrm{n}=15)\end{array}$ & $\begin{array}{l}\text { Healthy controls } \\
\text { (group III) } \\
(\mathrm{n}=10)\end{array}$ & $P$ value \\
\hline $\begin{array}{l}\text { Number of positive } \\
\text { (percentage) }\end{array}$ & $12(70.6 \%)$ & $7(46.7 \%)$ & $1(10 \%)$ & $\begin{array}{l}* \mathrm{P}<0.05 \\
\text { significant }\end{array}$ \\
\hline $\begin{array}{l}\text { Levels of TNF- } \alpha \\
(\mathrm{pg} / \mathrm{ml}) \\
{[\text { for patients : }} \\
\text { mean } \pm \mathrm{SD} \text { (range)] }\end{array}$ & $\begin{array}{c}96.1 \pm 33.2 \\
(39.7-385.1)\end{array}$ & $\begin{array}{c}75.7 \pm 27.4 \\
(29.8-216.3)\end{array}$ & 24.6 & $\begin{array}{l}* \mathrm{P}<0.05 \\
\text { significant }\end{array}$ \\
\hline Group II versu & $\begin{array}{l}\text { group II } \\
\text { group III } \\
\text { group III }\end{array}$ & $\begin{array}{l}\mathrm{P}<0.05 \\
\mathrm{P}<0.05 \\
\mathrm{P}<0.05\end{array}$ & & \\
\hline
\end{tabular}

Serum levels of IL-12 correlated positively with serum TNF- $\alpha$ levels in patients with active RA ( $\mathrm{r}=0.493)$ and in patients with inactive RA ( $\mathrm{r}=0.474)$ (Table 4). 
Daad F.I. El Fouhil et al

Table (4) :Correlation between serum IL-12 and TNF- $\alpha$ in patients with active and inactive RA.

\begin{tabular}{|c|c|c|c|c|c|}
\hline \multirow[b]{2}{*}{ RA patients } & \multicolumn{2}{|l|}{ IL-12 } & \multicolumn{2}{|l|}{$\mathrm{TNF}-\alpha$} & \multirow[b]{2}{*}{$\mathrm{r}$} \\
\hline & +ve $(\%)$ & $\underset{(\text { range) }}{\operatorname{mean}} \pm \mathrm{SD}$ & $+\mathrm{ve}(\%)$ & $\begin{array}{l}\text { mean } \pm S D \\
(\text { range })\end{array}$ & \\
\hline $\begin{array}{l}\text { Active RA patients } \\
\text { (group I) } \\
(\mathrm{n}=17)\end{array}$ & $\begin{array}{l}13 \\
(76.5 \%)\end{array}$ & $\begin{array}{l}57.9 \pm 11.8 \\
(16.6-98.3)\end{array}$ & $\begin{array}{l}12 \\
(70.6 \%)\end{array}$ & $\begin{array}{l}96.1 \pm 33.2 \\
(39.7-385.1)\end{array}$ & $\mathrm{r}=0.493$ \\
\hline $\begin{array}{l}\text { Inactive RA patients } \\
\text { (group II) } \\
(\mathrm{n}=15)\end{array}$ & $6(40 \%)$ & $\begin{array}{l}28.6 \pm 8.5 \\
(10.7-70.4)\end{array}$ & $7(46.7 \%)$ & $\begin{array}{l}75.7 \pm 27.4 \\
(29.8-216.3)\end{array}$ & $\mathrm{r}=0.474$ \\
\hline
\end{tabular}

\section{Discussion :}

RA is a chronic inflammatory disease with progressive articular damage often associated with systemic manifestations (Klimiuk et al., 2001).

Several clinical variables representing a set of disease activity measures were defined by the American College of Rheumatology (ACR) and were evaluated in several studies (Felson et al., 1993; Kim et al., 2000).

In the present study, two groups of RA patients [patients with active RA (group I) and patients with inactive RA (group II)] were evaluated according to the ACR core set measures of disease activity and were compared to each other, and it was found that there was no difference in age, sex, disease duration, degree of disability or physician's and patient's global assessments between both groups of patients $(\mathrm{P}>0.05)$. However patients with active RA (group I) had significantly higher tender joint score, swollen joint score, visual analogue pain scale, ESR and CRP compared to patients with inactive RA (group II) $(\mathrm{P}<0.05)$. These results are in agreement with the results obtained by Kim et al. (2000).

The aetiology and pathogenesis of RA are incompletely resolved (Klimiuk et al., 2001). Analysis of cytokines in RA has attracted a particular interest, as many cytokines are involved in the regulation of the immune and the inflammatory responses (Steiner et al., 1999).

The role of IL-12 has been addressed in the pathogenesis of RA. The administration of IL-12 enhanced disease expression and severity in an animal model of RA (Leonard et al., 1995). A blockade of IL-12 during the induction of collagen-induced arthritis markedly attenuated the severity of arthritis (Malfait et al., 1998). It has been documented that $\mathrm{IL}-12$ is highly expressed by infiltrating macrophages and synovial lining cells in patients with RA (Sakkas et al., 1998).

Schlaak et al. (1996) found that patients with RA had significantly higher levels of IL-12 p 70, a biologically active form of $\mathrm{IL}-12$, in serum compared with osteoarthritis patients and healthy controls. Similar results were obtained by Kim et al. (2000) who found detectable levels of IL12 p 70 in the sera of 64 out of $152(42.1 \%)$ RA patients, 1 out of $69(1.4 \%)$ osteoarthritis patients and 5 out of $50(10 \%)$ healthy controls with significantly higher levels of $\mathrm{IL}-12$ in the sera of RA patients compared with osteoarthritis patients and healthy controls. They concluded that IL-12 levels reflect RA disease activity and an IL-12 blockade could be useful for the treatment of RA.

In the present study, IL-12 p 70 was determined in the sera of active and inactive RA patients and healthy controls, and it was found that 13 out of $17(76.5 \%)$ active RA patients, 6 out of $15(40 \%)$ inactive RA patients and 1 out of $10(10 \%)$ healthy controls had detectable levels of IL-12 in serum, with significantly higher detectability of IL-12, and significantly higher serum levels of $\mathrm{IL}-12$ in patients with active RA than in patients with inactive RA and the healthy control $(\mathrm{P}<0.05)$. So active RA was found to be associated with elevated serum levels of IL-12. These results agreed with the results obtained by 
Yilmaz et al. (2001) who found that in juvenile RA patients, serum IL-12 levels during the active period of the disease were greater than in the controls, and there was a marked decrease in serum IL-12 levels when the patients entered the inactive phase of the disease. They concluded that IL-12 may play an important role in juvenile RA and may be used as a marker of disease activity. While Cordero et al. (2001) found that IL-12 levels were significantly higher in the sera of RA patients compared with the healthy controls, independently of disease activity.

Concerning $\mathrm{TNF}-\alpha$, it is a key mediator of inflammation and immunity, acting through its receptors expressed on all cells of the body. However, its overproduction may also lead to pathological changes. The latter situation occurs often in chronic inflammatory diseases as RA (Ziolkowska and Mastinski, 2003).

TNF- $\alpha$ is known to play a pivotal role in RA pathogenesis (Brennan et al., 1992), and there is an increasing evidence that implicates this cytokine, as well as $\mathrm{IL}-1$, as contributing factors in the inflammatory, and perhaps the destructive manifestation of RA (Moreland, 1999). Apart from exerting direct pathogenic effects, $\mathrm{TNF}-\alpha$ acts as a potent paracrine molecule inducing other proinflammatory molecules such as IL-1, granulocyte-monocyte colony stimulating factor, prostaglandin $\mathrm{E}_{2}$ and platelet activating factor. These secondary mediators can amplify the inflammatory reaction as well (Van den Berg and Van Lent, 1996).

The successful introduction of antitumour necrosis factor treatment in clinical practice confirmed the biological relevance of $\mathrm{TNF}-\alpha$ function in chronic inflammatory conditions in human, mainly in the pathogenesis of inflammatory bowel diseases and RA (Sfikakis and Kollias, 2003).

In the present study, $\mathrm{TNF}-\alpha$ was detected in serum in 12 out of $17(70.6 \%)$ active RA patients, 7 out of $15(46.7 \%)$ inactive RA patients and 1 out of $10(10 \%)$ healthy control subjects, with significantly higher detectability and significantly higher serum levels of TNF- $\alpha$ in active RA patients than in inactive RA patients and the healthy control $(\mathrm{P}<0.05)$. These results were consistent with the results obtained by Tetta et al. (1990) who detected TNF- $\alpha$ in the sera of most RA patients [ 9 out of 15 patients $(60 \%)$ ], with high levels of TNF- $\alpha$ in the sera of active RA patients.

Other studies investigated $\mathrm{TNF}-\alpha$ in the serum of RA and osteoarthritis patients, and they found that serum TNF- $\alpha$ levels were higher in patients with RA than in those with osteoarthritis (Steiner et al., 1999; Klimiuk et al., 2001).

In our study, inactive RA patients, as well as active RA patients, had significantly higher detectability of IL-12 and $\mathrm{TNF}-\alpha$ in serum, and significantly higher serum levels of IL-12 and TNF- $\alpha$ compared to the healthy control subjects $(\mathrm{P}<0.05)$, which may reflect the role of IL12 and TNF- $\alpha$ in the pathogenesis of RA.

Correlating IL-12 with TNF- $\alpha$ in RA disease, Brennan et al. (1992) stated that IL-12 can induce the production of proinflammatory cytokines, including $\mathrm{TNF}-\alpha$, which contribute to the signs and symptoms of RA. Moreover, the levels of these cytokines correlate well with the activity markers of RA.

In the present study, serum levels of IL-12 correlated positively with serum TNF $-\alpha$ levels in patients with active RA $(\mathrm{r}=0.493)$ and those with inactive RA $(\mathrm{r}=0.474)$. This result agreed with the results obtained by Kim et al. (2000). In addition, in our study, elevated serum levels of $\mathrm{IL}-12$ and TNF- $\alpha$ were associated with clinical and laboratory parameters of RA disease activity, and this agreed with the study done by Brennan et al. (1992).

In conclusion, significantly elevated serum levels of IL-12 and TNF- $\alpha$ were found to be associated with clinical and laboratory markers of activity of RA, so measurement of serum IL-12 and TNF- $\alpha$ levels could be used for assessment of RA activity. Serum levels of IL-12 correlated positively with serum $\mathrm{TNF}-\alpha$ levels and both cytokines may play an important role in the pathogenesis and inflammatory activity of RA. 


\section{References :}

1. Brennan F.M., Maini R.N. and Feldmann M. (1992). TNF- $\alpha-$ a pivotal role in rheumatoid arthritis. Br. J. Rheumatol.; 31 : 293-298.

2. Cordero O.J., Salgado F.J., Mera-Varela A. and Nogueira M. (2001). Serum interleukin-12, interleukin-15, soluble CD26, and adenosine deaminase in patients with rheumatoid arthritis. Rheumatol. Int.; 21 (2) : 69-74.

3. Ehrhardt R.O., Ludviksson B.R., Gray B., Neurath M. and Strober W. (1997). Induction and prevention of colonic inflammation in IL-2 deficient mice. J. Immunol.; 158: 566-573.

4. Felson D.T., Anderson J.J. and Boers M. (1993). The American College of Rheumatology preliminary core set of disease activity measures for rheumatoid arthritis clinical trials. Arthritis Rheum.; 36: 729-740.

5. Kim W.U., Min S.Y., Cho M.L., Youn J., Min J.K., Lee S.H., Park S.H., Cho C.S. and Kim H.Y. (2000). The role of IL-12 in inflammatory activity of patients with rheumatoid arthritis (RA). Clin. Exp. Immunol.; 119: 175-181.

6. Klimiuk P.A., Sierakowski S., Latosiewicz R., Cylwik B., Skowronski J. and Chwiecko J. (2001). Serum cytokines in different histological variants of rheumatoid arthritis. The Journal of Rheumatology; 28(6) : 1211-1217.

7. Leonard J.O., Waldburger K.E. and Goldman S.J. (1995). Prevention of experimental autoimmune encephalomyelitis by antibodies against interleukin-12. J. Exp. Med.; 181: 381-386.

8. Malfait A.M., Butler D.M., Presky D.H., Maini R.N., Brennan F.M. and Feldmann M. (1998). Blockade of IL-12 during the induction of collagen-induced arthritis (CIA) markedly attenuates the severity of the arthritis. Clin. Exp. Immunol.; 111: 377-383.

9. Moreland L.W. (1999). The role of cytokines in rheumatoid arthritis: inhibition of cytokines in therapeutic trials. Drugs Today; 35 (4) : 309-319.

10. Peters M. (1996). Action of cytokines on the immune response and viral interactions : an overview. Hepatology; 23: 909-916.
11. Peters M.G. (1999). Immunologic aspects of liver disease. In : Schiff E.R., Sorrell M.F. and Maddrey W.C. (ed.). Diseases of the liver, Volume $2,8^{\text {th }}$ ed., LippincottRaven Press, Philadelphia, New York, p. 909-917.

12. Sakkas L.I., Johanson N.A., Scanzello C.R. and Platsoucas C.D. (1998). Interleukin-12 is expressed by infiltrating macrophages and synovial lining cells in rheumatoid arthritis and osteoarthritis. Cell. Immunol.; 188: 105-110.

13. Schlaak J.F., Pfers I., Meyer Zum Buschenfelde K.H. and MarkerHermann E. (1996). Different cytokine profiles in the synovial fluid of patients with osteoarthritis, rheumatoid arthritis and seronegative spondylarthropathies. Clin. Exp. Rheumatol.; 14: 155-162.

14. Sfikakis P.P. and Kollias G. (2003). Tumour necrosis factor biology in experimental and clinical arthritis. Curr. Opin. Rheumatol.; 15(4): 380-386.

15. Steiner G., Tohidast-Akrad M., Witzmann G., Vesely M., StudnickaBenke A., Gal A., Kunaver M., Zenz P. and Smolen J.S. (1999). Cytokine production by synovial Tcells in rheumatoid arthritis. Rheumatology; 38: 202-213.

16. Tetta C., Camussi G., Modena V., Di Vittorio C. and Baglioni C. (1990). Tumour necrosis factor in serum and synovial fluid of patients with active and severe rheumatoid arthritis. Ann. Rheum. Dis.; 49: 665-667.

17. Trinchieri G. (1995). Interleukin-12 : a proinflammatory cytokine with immunoregulatory functions that bridge innate resistance and antigen-specific adaptive immunity. Annu. Rev. Immunol.; 13: 251-276.

18. Van den Berg W.B. and Van Lent P.L. (1996). The role of macrophages in chronic arthritis. Immunobiology; 195: 614-623.

19. Yilmaz M., Kendirli S.G., Altintas D., Bingol G. and Antmen B. (2001). Cytokine levels in serum of patients with juvenile rheumatoid arthritis. Clin. Rheumatol.; 20(1) : 30-35.

20. Ziolkowska M. and Mastinski W. (2003). Laboratory changes on anti-tumour necrosis factor treatment in rheumatoid arthritis. Curr. Opin. Rheumatol.; 15 (3): 267-273. 


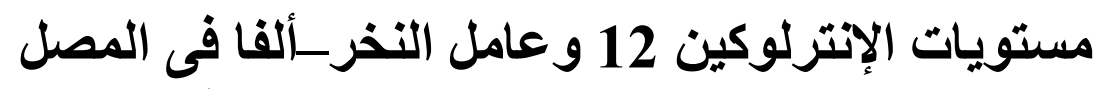

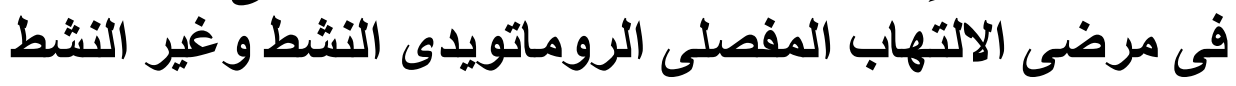

\section{دعد فتح الله إبراهيم الفحيل ـ أماتى محمد عبد الوهاب*

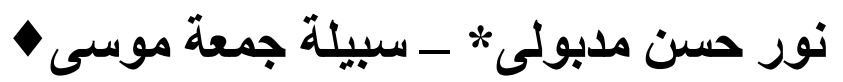

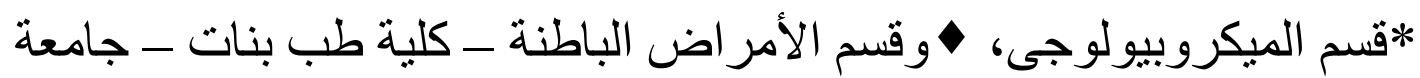
الأز هرا هر الأز

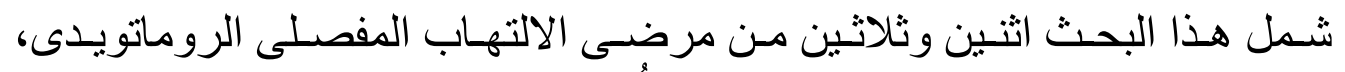

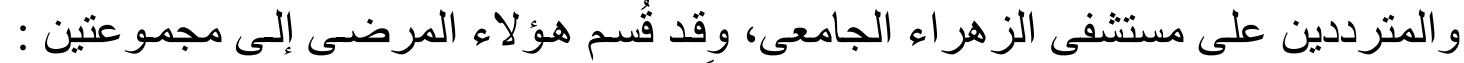

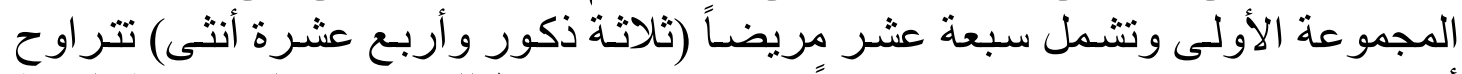

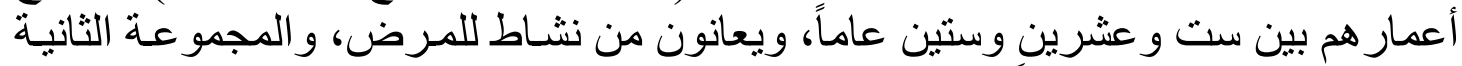

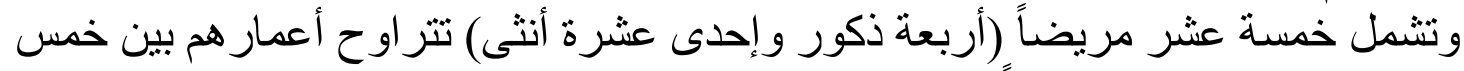

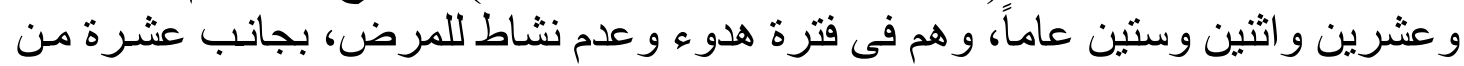

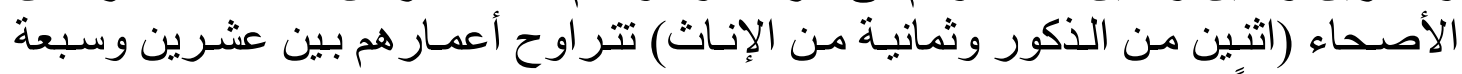

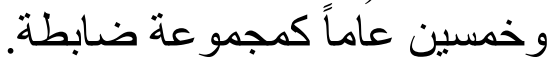

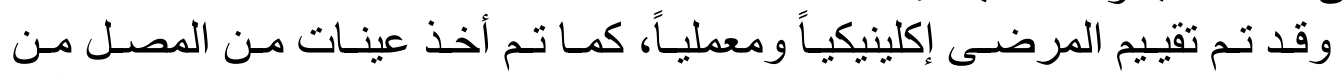
المرضى ومن المجمو عـة الضـابطة لقيـاس مستويات الإنترلوكين 12 و عامـل النخر ـألفـا تخدام

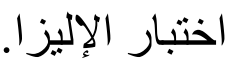

وقد أوضـح البحث عدم وجود فروق ذات دلالة إحصـائية بين مرضسى الالتهاب

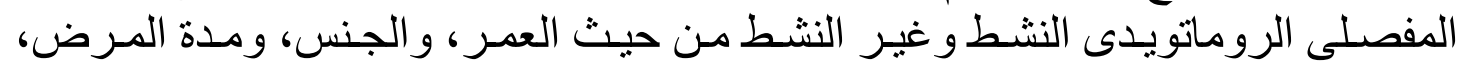
ودرجة الإعاقة، و التقييم العام للمريض وللطبيب، ولكن وُجدت فروق ذات دلالـة إحصـائية

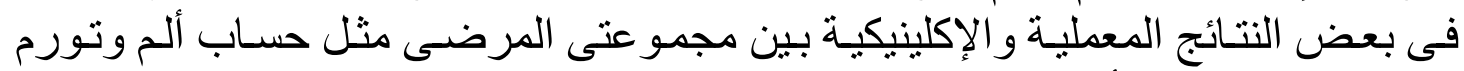

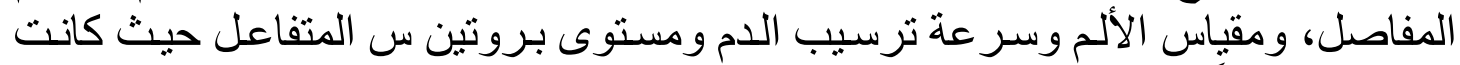

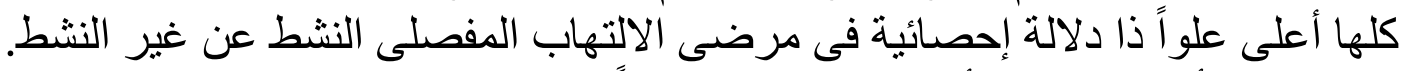

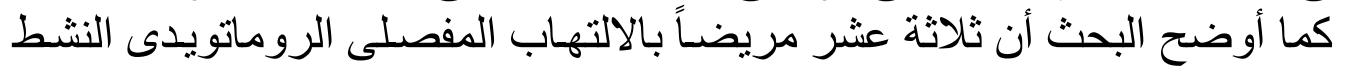

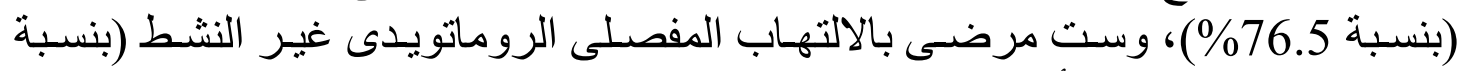

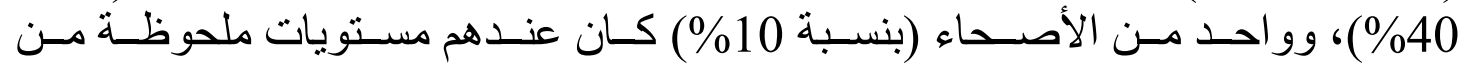
الإنترلوكين 12 فى المصل.

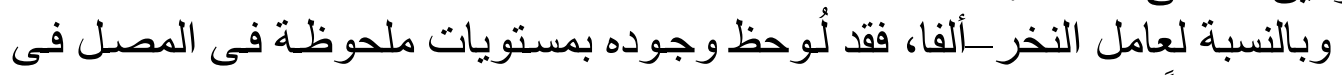

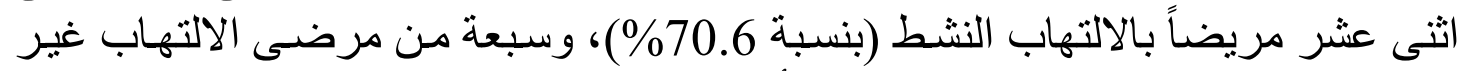

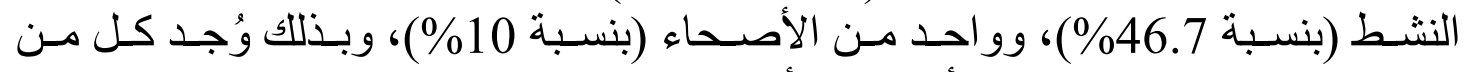

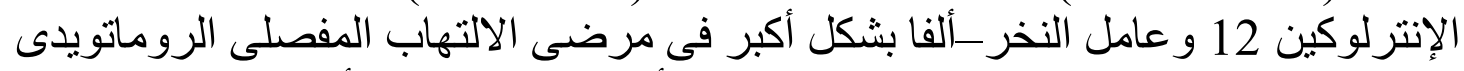

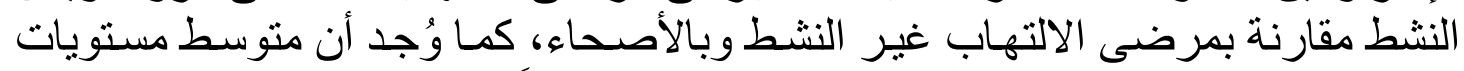

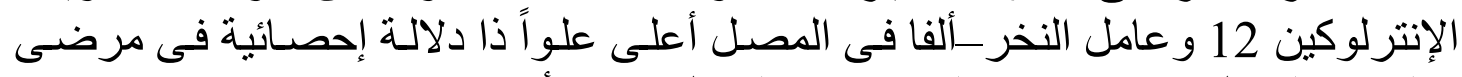
الالتهاب النشط عن مرضى الالتهاب غير النشط و عن النّ الأصحاء. 


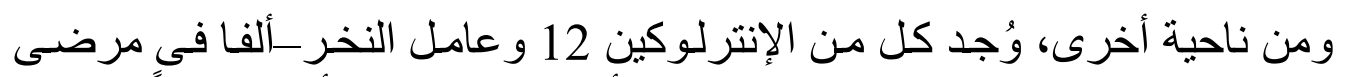

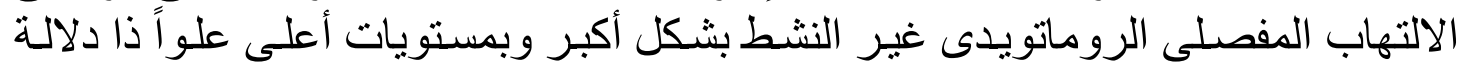

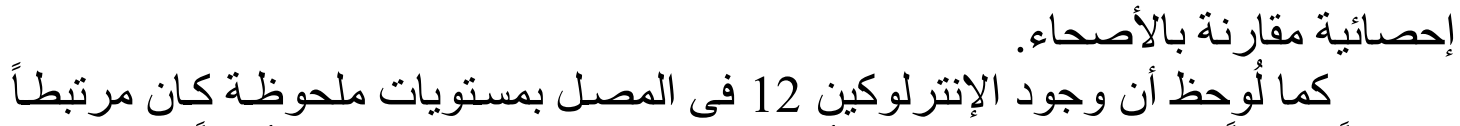

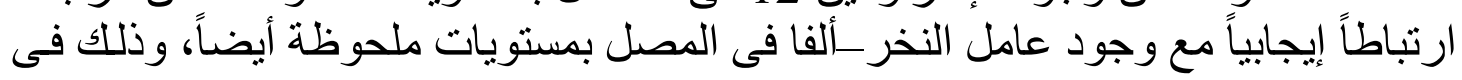

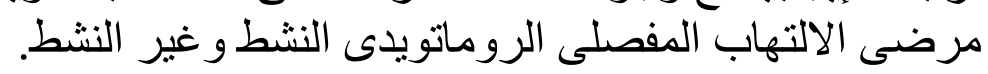

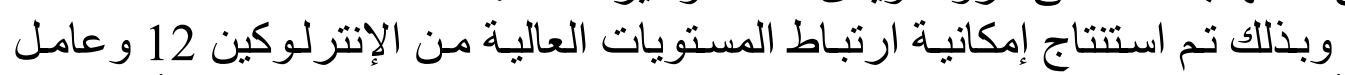

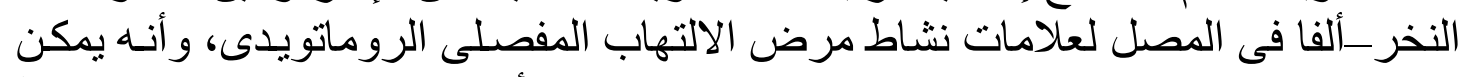

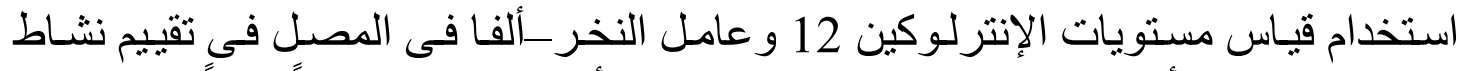

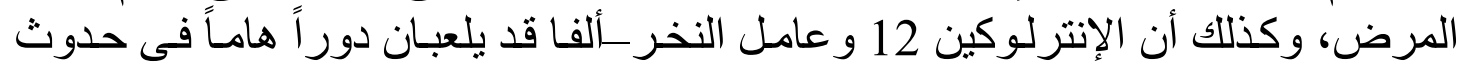
المرض ونشاطه. 